\title{
Antidiabetic, Antihyperlipidaemic and Protective effects on Kidney and Liver functions by leaf extracts of Eriosema psoraleoides G. Lam (Leguminosae)
}

Nkemdirim A. Elechi ${ }^{*}$, Kio A. Abo

Department of Pharmacognosy and Phytotherapy, Faculty of Pharmaceutical Sciences, University of Port Harcourt, Nigeria

DOI: $10.36348 /$ sjmps.2020.v06i06.012 $\quad$ | Received: 20.06.2020 | Accepted: 27.06 .2020 | Published: 30.06 .2020

*Corresponding author: Nkemdirim A. Elechi

\section{Abstract}

Eriosema psoraleoides is a plant used in_ethnomedicine in the South East of Nigeria to manage conditions related to diabetes. The present research work is aimed at investigating the antidiabetic potentials of the leaves of this plant. The plant was collected in Nsukka, Nigeria, and authenticated by a taxonomist. Phytochemical screening was carried out on the leaves of the plant using standard procedures. The acute toxicity was tested using the Lorke's method. Extraction was carried out successively with n-hexane, ethylacetate and $80 \%$ aq. Methanol, by maceration. In vivo tests were carried out on alloxan-induced diabetic male Wistar rats, using these three extracts for 14 days. Glibenclamide, $4 \mathrm{mg} / \mathrm{kg}$ body weight was used as positive control. Statistical analysis was carried out using standard error of the mean and student's t-test. Blood glucose measurements were done with a glucometer. Phytochemical results showed the presence of tannins, flavonoids, steroids, anthraquinones, and reducing sugars. In the toxicity test no deaths were recorded even at $5000 \mathrm{mg} / \mathrm{kg}$ body weight of the rats. In the acute antidiabetic test no significant reduction in blood glucose levels were recorded for any of the extracts in the first 180 minutes on day 1 . In the chronic test, the $n$-hexane and ethylacetate extracts demonstrated significant $(\mathrm{p}<0.05)$ reductions in blood glucose levels up to $77.5 \%$, and $75.3 \%$, on the $14^{\text {th }}$ day, respectively, compared to $79.3 \%$ for Glibenclamide. The biochemical results show the plant has antihyperlipidaemic, hepatic and renal protective effects. Our results tend to justify the use of this plant in ethnomedicine.

Keywords: Eriosema psoraleoides, (Leguminosae), Antidiabetic, Antihyperlipidaemic, Alloxan-induced diabetic Wistar rats.

Copyright @ 2020: This is an open-access article distributed under the terms of the Creative Commons Attribution license which permits unrestricted use, distribution, and reproduction in any medium for non-commercial use (NonCommercial, or CC-BY-NC) provided the original author and source are credited.

\section{INTRODUCTION}

Diabetes mellitus is a disease that results from a deficiency in insulin secretion, resistance to the effect of insulin on target cells, or a combination of both [1]. It manifests as hyperglycemia that is often accompanied by polyuria, polydipsia and glycosuria [2]. Chronic diabetes leads to some end organ damage which may include nephropathy, liver damage, neuropathy, and eye damage (diabetic retinopathy). Diabetes also leads to changes in lipid profile that could result in atherosclerosis, and cardio-vascular disease (CVD) [3].

There are various types of diabetes, and the two main types are the Type I (Insulin Dependent Diabetes) and the Type II (Non-Insulin Dependent Diabetes). Drug treatment include insulin for IDD, and oral hypoglycemic agents for the NIDD.
WHO projects that diabetes will be the $7^{\text {th }}$ leading cause of death in 2030 [4]. It is predicted that the prevalence of diabetes mellitus in adults will increase in the next two decades, and that much of the increase will occur in developing countries [5]. It has also been reported that $80 \%$ of people in developing countries depend on herbal medicine to manage their ailments.

Medicinal plants have proven to be a veritable source of drugs for the management of various diseases $[6,7]$. An example includes the use of Artemisia annua for the treatment of malaria caused by Plasmodium falciparum [8]. The search for effective, less expensive drugs with less severe side effects, and better compliance, has led to extensive research on antidiabetics of natural origin. A number of plant extracts have been reported to exhibit antidiabetic activities, including Persia americana [9], Momordica charantia [10], and Vernonia amygdalina [11]. One of 
the plants used in ethnomedicine to manage diabetes is Eriosema psoraleoides, in the South Eastern parts of Nigeria. It is also used in the treatment of venereal diseases, dysentery and as diuretics. The present research work is aimed at investigating the activity of this species of the plant, using the alloxan-induced diabetic rat model.

E. psoraleoides is an erect herb or sub-woody shrub $1-2.5 \mathrm{~m}$ high from a perennial woody root-stock. The leaves are 3-foliolate, and rarely 1-foliolate on the lower leaves. The leaflets are elliptic-oblong to obvateelliptic, $2.5-9.5 \mathrm{~cm}$, finely pubescent above, paler, velvety with prominent venation beneath. Flowers in many-flowered, terminal and axillary racemes, golden yellow, pods $1-2 \mathrm{~cm}$, ovate to almost circular, and covered in long spreading hairs [12]. Synonyms include Crotalaria psoraleoides Lam., Eriosema cajanoides (Guill. \& Perr.) Hook.f., and Rhynchosia psoraleoides (Lam) DC., with the common name "Canary pea" (English).

Previous reports indicate that five pyranoisoflavones were isolated from the species Eriosema kraussianum, with penile relaxant activity [13]. Chromones and phenolic compounds with antifungal activity have been reportedly isolated from the roots of another species, E. tuberosum [14]. The chromones, Eriosematin D and Eriosematin E, were active against Candida cucumerinuum and C. albicans. Also, from the same plant has been isolated an isoflavonoid compound with antiviral activity [15]. The findings of Ojewole, et. al., 2006 [16] showed that the two hydro-ethanol extractives of rootstock of E. kraussianum possess hypoglycemic and secondary vasorelaxant effects in experimental rat models. Chukwuemeka, 2011[17], reported that the aqueous and ethanol extracts of the leaves of Eriosema psoraleoides caused significant inhibition of lipid peroxidation in alloxan-induced diabetic rat model. Phenolic derivatives have been isolated from the roots of E. tuberosum [18]. The simple phenols include 4-hydroxybenzoic acid, hydroquinone, vanillic acid and Eriosematin F. The other three phenols are glycosides and include Arbutin C, Eriosemaside A and Eriosemaside B.

\section{MATERIALS AND METHODS}

The plant material was collected from Nsukkka, Nigeria, and was identified by Mr. A. O. Ozioko of the Biodiversity and Conservation Organisation (BDC), Nsukka, Nigeria, with herbarium number INTERCEDD 968.

Healthy Wistar albino rats (male and female) with weight range of about 180-200g were selected for this study. They were obtained from the animal house of the Department of Experimental Pharmacology, Faculty of Pharmaceutical Sciences, University of Port Harcourt. The rats were fed with standard feed and water ad libitum. They were properly housed in clean uniform cages and allowed to acclimatize for two weeks before commencement of the study. Approval was obtained from the Research Ethics Committee of the University of Port Harcourt for this study. The Glibenclamide used was bought from a Pharmacy shop in Port Harcourt, and the n-hexane, ethylacetate and methanol were analytical grade solvents.

\section{Phytochemical screening}

Standard test procedures $[19,20]$ were used to screen the plant material for the presence of phytochemicals.

\section{Extraction of Plant Material}

A $2 \mathrm{~kg}$ of the dried leaves of Eriosema psoraleoides (Leguminosae) was powdered and successively extracted with n-hexane, ethylacete and $80 \%$ aqueous ethanol for three days, using the maceration method. The plant material was then filtered, the filtrate concentrated in a rotary evaporator, and then the extract was air-dried and stored in a desiccator until ready for use.

\section{Toxicity Test}

The median lethal dose $\left(\mathrm{LD}_{50}\right)$ of the ethylacetate leaf extract was determined by Lorke's method [21]. A total of 18 rats were used for the studies. The studies were conducted in two stages with the extract. In the first stage, three groups of three rats each were given per oral doses of 10, 100, and $1000 \mathrm{mg} / \mathrm{kg}$ body weight of the extract, respectively. The rats were observed for $24 \mathrm{hrs}$ for number of deaths and behavioural changes (signs of toxicity). In the second stage, based on the percentage survival rates, further increased doses of 1600,2900 , and $5000 \mathrm{mg} / \mathrm{kg}$ body weight were administered per oral to three groups of three rats, respectively. The rats were observed for $24 \mathrm{hrs}$, and the number of deaths were recorded. The $\mathrm{LD}_{50}$ would be calculated as the geometric mean of the highest non-lethal and lowest lethal doses, but if no deaths occur at the highest dose then the plant would be considered safe.

\section{Alloxan-induced Antidiabetic Test}

Diabetes was induced in the rats through the intraperitoneal administration of $150 \mathrm{mg}$ of alloxan monohydrate $/ \mathrm{kg}$ body weight of the animal [22]. After 4 days, the animals that showed blood glucose levels above $200 \mathrm{mg} / \mathrm{dl}$ were selected. The animals were divided into six groups of five rats each, I-VI. Rats in group I were not induced with Alloxan, and served as the normal control. Group II contained the diabetic untreated rats and served as the negative control, while Group III were treated with the control drug Glibenclamide, serving as the positive control. Animals in groups IV-VI were each treated with one of the three extracts, respectively. 


\section{Treatment Schedule}

Day 1: The animals were fasted overnight but allowed access to water prior to oral treatment. Basal blood glucose level at zero time (fasting) were determined before oral administration. The Glibenclamide $(4 \mathrm{mg} / \mathrm{kg})$ and the various extracts at $1000 \mathrm{mg} / \mathrm{kg}$ were administered immediately to the rats in appropriate cages and blood glucose levels determined at intervals of 60 minutes for the next 3 hours, on day 1 [22]. Day 2-14: Rats in cages III - VI were treated with glibenclamide and the extracts, separately, daily. But the rats in cages I and II received only food and water. The blood glucose levels of the rats in the various groups were measured two hours after the treatment, and recorded. At the end of the $14^{\text {th }}$ day, the animals were anaesthetized, sacrificed and their blood withdrawn and tested for the lipid profile and biochemical parameters.

\section{STATISTICAL ANALYSIS}

The test results were expressed as a mean \pm Standard Error of the Mean (SEM). The statistical analysis was carried out with one-way analysis of variance (ANOVA), using GraphPad Prism version 6. The significance of the differences between the treated and the control animals were determined using the student's t-test.

\section{RESULTS}

The phytochemical analysis of the powdered leaves of this plant gave positive results for flavonoids, tannins, combined anthraquinone, carbohydrates, reducing sugars and steroidal nucleus. This is similar to the results reported by Chukwuemeka, 2011, although we could not confirm presence of alkaloids.

Table-1: Percentage yield of crude extracts of the leaf of $E$. psoraleoides.

\begin{tabular}{|l|l|l|l|}
\hline PLANT MATERIAL & $\begin{array}{l}\text { n-HEXANE } \\
\text { EXTRACT }\end{array}$ & $\begin{array}{l}\text { ETHYLACETATE } \\
\text { EXTRACT }\end{array}$ & $\begin{array}{l}\text { 80\% METHANOL } \\
\text { EXTRACT }\end{array}$ \\
\hline Weight of powdered leaves, 2kg. & $15.1 \mathrm{~g}(0.76 \%)$ & $32.5 \mathrm{~g}(1.6 \%)$ & $9.7 \mathrm{~g}(0.49 \%)$ \\
\hline
\end{tabular}

Table-2: Acute toxicity result for $E$. psoraleoides $\left(\mathrm{LD}_{50}\right.$ TEST)

\begin{tabular}{|l|l|l|l|}
\hline DAY & DOSE of Extract (mg/Kg body weight) & SURVIVAL & DEATHS \\
\hline 1 & 10 & $3 / 3$ & $0 / 3$ \\
& 100 & $3 / 3$ & $0 / 3$ \\
& 1000 & $3 / 3$ & $0 / 3$ \\
\hline 2 & 1600 & $3 / 3$ & $0 / 3$ \\
& 2900 & $3 / 3$ & $0 / 3$ \\
& 5000 & $3 / 3$ & $0 / 3$ \\
\hline
\end{tabular}

Table-3: Effect of various extracts of $E$. psoraleoides on blood glucose levels of alloxan-induced diabetic rats (Day 1)

\begin{tabular}{|l|l|l|l|l|}
\hline TREATMENT (mg per Kg body weight) & $\mathbf{0 ~ h r .}$ & $\mathbf{1}$ hr. & $\mathbf{2}$ hr. & $\mathbf{3 ~ h r .}$ \\
\hline n-hexane extract $(1000 \mathrm{mg})$ & $368 \pm 8.1$ & $317 \pm 7.8(18.9 \%)$ & $293 \pm 3.1(24.7 \%)$ & $292 \pm 2.9(25.3 \%)$ \\
\hline Ethylacetate extract $(1000 \mathrm{mg})$ & $391 \pm 7.2$ & $337.5 \pm 6.5(13.7 \%)$ & $296.5 \pm 3.3(23.8 \%)$ & $290 \pm 2.8(25.8 \%)$ \\
\hline $80 \%$ aq. Methanol extract $(1000 \mathrm{mg})$ & $389 \pm 6.6$ & $387 \pm 7.6(1.0 \%)$ & $387 \pm 4.1(0.5 \%)$ & $388 \pm 3.6(0.7 \%)$ \\
\hline Glibenclamide $(4 \mathrm{mg})$ & $370 \pm 5.8$ & $368 \pm 6.9(5.9 \%)$ & $359 \pm 3.9(7.7 \%)$ & $350 \pm 3.4(10.5 \%)$ \\
\hline Diabetic Untreated & $390 \pm 3.2$ & $391 \pm 2.8$ & $389 \pm 3.3$ & $391 \pm 3.9$ \\
\hline Normal & $121 \pm 2.7$ & $120 \pm 1.9$ & $121 \pm 2.1$ & $122 \pm 2.6$ \\
\hline
\end{tabular}

Each value represents mean \pm SEM, where $n=5$; figures in parenthesis represent the $\%$ decrease in blood glucose level.

Table-4: Effect of various extracts of $E$. psoraleoides on blood glucose level of alloxan-induced diabetic rats (Day 2-14)

\begin{tabular}{|l|l|l|l|l|l|l|l|l|}
\hline $\begin{array}{l}\text { Treatment (mg } \\
\text { per kg body } \\
\text { weight) }\end{array}$ & DAY 2 & DAY 3 & DAY 4 & DAY 5 & DAY 6 & DAY 7 & DAY 10 & DAY 14 \\
\hline $\begin{array}{l}\text { n-hexane extract } \\
(1000 \mathrm{mg})\end{array}$ & $\begin{array}{l}393 \pm 3.2 \\
(-0.5 \%)\end{array}$ & $\begin{array}{l}262 \pm 2.7 \\
(33.2)\end{array}$ & $\begin{array}{l}* 207 \pm 2.9 \\
(46.8)\end{array}$ & $\begin{array}{l}* 166 \pm 1.9 \\
(57.2)\end{array}$ & $\begin{array}{l}240 \pm 2.2 \\
(37.5)\end{array}$ & $\begin{array}{l}230 \pm 2.1 \\
(39.3)\end{array}$ & $\begin{array}{l}* 203 \pm 2.1 \\
(45.5)\end{array}$ & $\begin{array}{l}* 87.5 \pm 0.7 \\
(77.5)\end{array}$ \\
\hline $\begin{array}{l}\text { Ethylacetate extract } \\
(1000 \mathrm{mg})\end{array}$ & $384.5 \pm 3.7$ & $289 \pm 3.1$ & $* 213 \pm 2.8$ & $* 189 \pm 1.8$ & $* 143 \pm 1.9$ & $* 139 \pm 1.8$ & $* 121 \pm 1.9$ & $* 96 \pm 1.1$ \\
$(1.7 \%)$ & $(26.3)$ & $(45.2)$ & $(51.3)$ & $(62.8)$ & $(63.3)$ & $(68.7)$ & $(75.3)$ \\
\hline $\begin{array}{l}80 \% \text { aq. Methanol } \\
\text { extract (1000mg) }\end{array}$ & $380 \pm 4.1$ & $287 \pm 2.9$ & $242 \pm 2.8$ & $225 \pm 2.2$ & $267 \pm 2.8$ & $250 \pm 2.3$ & $249 \pm 2.3$ & $233 \pm 2.1$ \\
$(2.8 \%)$ & $(26.8)$ & $(37.8)$ & $(42 \%)$ & $(30.5)$ & $(34 \%)$ & $(35.7)$ & $(40 \%)$ \\
\hline Glibenclamide & $355 \pm 3.1$ & $321 \pm 2.8$ & $281 \pm 1.9$ & $227 \pm 2.4$ & $* 219 \pm 2.9$ & $* 176 \pm 1.6$ & $* 109 \pm 0.9$ & $* 80.5 \pm 0.9$ \\
$(4 \mathrm{mg})$ & $(9.2 \%)$ & $(18.1)$ & $(27.8)$ & $(41.5)$ & $(43 \%)$ & $(53.6)$ & $(71.8)$ & $(79.3)$ \\
\hline Diabetic Untreated & $391 \pm 3.2$ & $392 \pm 2.9$ & $389 \pm 3.1$ & $388 \pm 3.1$ & $384 \pm 3.3$ & $379 \pm 3.2$ & $387 \pm 3.4$ & $388 \pm 2.9$ \\
\hline Normal & $123 \pm 1.9$ & $122 \pm 1.6$ & $121.5 \pm 1.1$ & $123 \pm 1.9$ & $119 \pm 1.1$ & $121 \pm 1.2$ & $120 \pm 0.9$ & $119 \pm 1.1$ \\
\hline
\end{tabular}

Each value represents mean \pm SEM, where $n=5$; figures in parenthesis represent the \% decrease in blood glucose level: * represent the values significantly different from the control $(\mathrm{p}<0.05)$ 
Nkemdirim A. Elechi \& Kio A. Abo; Saudi J Med Pharm Sci, June, 2020; 6(6): 474-479

Table-5: Effect of leaf extracts of $E$. psoraleoides on lipid profile of diabetic rats on Day 14

\begin{tabular}{|l|l|l|l|l|l|}
\hline Treatment & Dose $\mathbf{( m g / k g )}$ & TC $(\mathbf{m g} / \mathbf{d l})$ & TG $(\mathbf{m g} / \mathbf{d l})$ & LDL $(\mathbf{m g} / \mathbf{d l})$ & HDL (mg/dl) \\
\hline n-Hexane extract & $1000 \mathrm{mg}$ & $85.23 \pm 0.39$ & $92.01 \pm 3.14$ & $* 7.81 \pm 1.36$ & $* 67.27 \pm 0.61$ \\
\hline Ethylacetate extract & $1000 \mathrm{mg}$ & $79.12 \pm 8.11$ & $89.32 \pm 5.62$ & $* 8.43 \pm 6.37$ & $* 68.22 \pm 10.11$ \\
\hline $80 \%$ Methanol extract & $1000 \mathrm{mg}$ & $88.21 \pm 8.13$ & $91.08 \pm 3.36$ & $18.33 \pm 9.67$ & $55.39 \pm 4.19$ \\
\hline Glibenclamide & $4 \mathrm{mg}$ & $107.33 \pm 21.61$ & $106.3 \pm 4.91$ & $22.71 \pm 5.16$ & $35.61 \pm 1.15$ \\
\hline Diabetic untreated (control) & - & $101.36 \pm 1.98$ & $99.81 \pm 3.21$ & $28.89 \pm 7.13$ & $39.91 \pm 4.17$ \\
\hline Normal & - & $86.31 \pm 2.9$ & $100.3 \pm 3.11$ & $26.76 \pm 1.12$ & $38.90 \pm 2.57$ \\
\hline
\end{tabular}

Each value represents mean \pm SEM, where $n=4$; * represent the values significantly different from the control $(\mathrm{p}<0.05)$.

$[\mathrm{TC}=$ Total cholesterol; $\mathrm{TG}=$ Triglycerides; $\mathrm{LDL}=$ Low density lipoproteins; HDL= High density lipoproteins $]$.

Table-6: Effect of various treatments of leaf extracts of $E$. psoraleoides on liver enzyme functions

\begin{tabular}{|l|l|l|l|l|}
\hline Treatment & Dose $(\mathbf{m g} / \mathbf{k g})$ & AST (U/L) & ALT (U/L) & ALP (U/L) \\
\hline n-Hexane extract & $1000 \mathrm{mg}$ & $* 140.18 \pm 2.12$ & $* 22.11 \pm 3.16$ & $* 18.37 \pm 2.61$ \\
\hline Ethylacetate extract & $1000 \mathrm{mg}$ & $* 144.61 \pm 23.13$ & $* 25.23 \pm 11.61$ & $* 20.16 \pm 11.37$ \\
\hline $80 \%$ Methanol extract & $1000 \mathrm{mg}$ & $* 201.67 \pm 10.33$ & $* 32.18 \pm 6.73$ & $* 23.23 \pm 6.11$ \\
\hline Glibenclamide & $4 \mathrm{mg}$ & $310.16 \pm 2.18$ & $49.21 \pm 2.37$ & $* 28.03 \pm 6.73$ \\
\hline Diabetic untreated (control) & - & $401.32 \pm 18.66$ & $58.11 \pm 5.61$ & $69.13 \pm 15.37$ \\
\hline Normal & - & $232.13 \pm 3.61$ & $44.51 \pm 1.31$ & $24.05 \pm 2.17$ \\
\hline
\end{tabular}

Each value represents mean \pm SEM, where $n=4 ; *$ represent the values significantly different from the control $(p<0.05)$.

[AST $=$ Aspartate aminotransferase; ALT = Alanine aminotransferase; ALP = Alkaline phosphatase.

Table-7: Result of various leaf extracts of $E$. psoraleoides on kidney function of diabetic rats

\begin{tabular}{|l|l|l|l|}
\hline Treatment & Dose $(\mathbf{m g} / \mathbf{k g})$ & Urea $(\mathbf{m g} / \mathbf{d l})$ & Creatinine $(\mathbf{m g} / \mathbf{d l})$ \\
\hline n-Hexane extract & $1000 \mathrm{mg}$ & $* 12.09 \pm 0.25$ & $* 1.13 \pm 0.17$ \\
\hline Ethylacetate extract & $1000 \mathrm{mg}$ & $* 11.18 \pm 0.21$ & $* 1.10 \pm 0.08$ \\
\hline $80 \%$ Methanol extract & $1000 \mathrm{mg}$ & $* 12.01 \pm 2.63$ & $* 1.15 \pm 0.06$ \\
\hline Glibenclamide & $4 \mathrm{mg}$ & $13.98 \pm 3.11$ & $1.29 \pm 0.14$ \\
\hline Diabetic untreated (control) & - & $15.61 \pm 7.22$ & $1.98 \pm 0.32$ \\
\hline Normal & - & $8.61 \pm 3.62$ & $0.89 \pm 0.09$ \\
\hline
\end{tabular}

Each value represents mean $\pm S E M$, where $n=4 ; *$ represent the values significantly different from the control $(p<0.05)$

\section{DiscuSSION}

The presence of flavonoids, tannins, anthraquinone, carbohydrates, and steroids were detected in the phytochemical screening of the leaves of this plant. In a review article, Saravanamuttu and Sudarsanam [23], reported the presence of several plant constituents as being responsible for their antidiabetic activity. Such constituents include saponins in Berberis vulgaris, non-starch polysaccharides of the fruiting bodies of the fungi Hericium erinaceus, and a flavone glucoside found in the flowers of Hibiscus vitifolius. Other active constituents listed in their report include alkaloids, flavonoids, triterpenoids, phenolics, iridoids, polysaccharides, steroids and inorganic ions. It is thus possible that the presence of some of these constituents may be responsible for the observed antidiabetic activity recorded with Eriosema psoraleoides in the present study. In the acute toxicity test (Table-2), no death was recorded even with the highest dose of $5000 \mathrm{mg} / \mathrm{Kg}$ body weight, this indicates that this plant is safe [21]. In the acute antidiabetic study, the extracts did not elicit a significant percent reduction in blood glucose levels in the animals, after 180 minutes (Table3 ). However, in the chronic antidiabetic study (Table4), the n-hexane and ethylacetate extracts demonstrated significant $(\mathrm{p}<0.05)$ antidiabetic activities at the dose levels of $1000 \mathrm{mg} / \mathrm{kg}$ body weight used for the study. The mean percent reductions in the blood glucose levels were $77.5 \%$ for the n-hexane, and $75.3 \%$ for the ethylacetate extracts at the 14th day. These figures are comparable to the percent reduction of $79.3 \%$ by the standard drug, Glibenclamide. However, the aqueous $80 \%$ methanol extract showed only $40 \%$ reduction at 14 days. In diabetes, serum cholesterol (TC), triglycerides (TG) and LDL levels are elevated [24]. The n-hexane and ethyl acetate extracts caused significant increases in the HDL level to 67.27 , and $68.22 \mathrm{mg} / \mathrm{dl}$ respectively, compared to the diabetic untreated value of 39.91 . However, a significant reduction to 7.81 , and $8.43 \mathrm{mg} / \mathrm{dl}$ of LDL was recorded for n-hexane and ethylacetate, respectively, down from 28.89 for the diabetic untreated (Table-5). The $80 \%$ aq. Methanol extract showed a reduction to $18.33 \mathrm{mg} / \mathrm{dl}$. On the other hand, the extracts did not cause any significant change in the TC and TG values in the animals, compared to the diabetic untreated figures. Increase in creatinine blood levels indicate a dysfunctional kidney as happens in diabetes [25]. In this study, significant decreases in the creatinine and urea levels were recorded by the three extracts (Table-7). Hyperuremia occurs in diabetes due to its decreased excretion or increased protein catabolism [26]. The results here show that the extracts 
may have a renal protective effect. Diabetes causes increased levels of the liver enzymes Aspartate aminotransferase (AST), Alanine aminotransferase (ALT), and Alkaline phosphatase (ALP) [27]. The three extracts caused significant reductions in all these enzymes, when compared to the control (Table-6).

\section{Conclusion}

Two out of the three extracts of the plant, that is, the n-hexane and ethylacetate extracts have demonstrated significant antidiabetic activity thus justifying its use in ethnomedicine. In addition, the extracts have shown that the plant is capable of protecting the liver and kidneys, and is effective in reducing hyperlipidaemia associated with diabetes. This suggests that the long-term administration of the plant extracts may protect against the cardiovascular complications of diabetes. Further work is ongoing to isolate the active constituents.

No Conflict Of Interest: The authors do hereby affirm that there are no conflicts of interest on this work.

\section{REFERENCES}

1. World Health Organization. (1999). Definition, Diagnosis and Classification of Diabetes Mellitus and its Complications. Accessed, https://apps.who.int, 20 ${ }^{\text {th }}$ May, 2020.

2. Celik, I., Yeğin, E., \& Odabaşoğlu, F. (2002). Effect of experimental diabetes mellitus on plasma lactate dehydrogenase and glutamic oxaloacetic transaminase levels in rabbits. Turkish Journal of Biology, 26(3), 151-154.

3. Goycheva, P., Gadjeva, V., \& Popov, B. (2006). Oxidative Stress and its Complications in Diabetes Mellitus. Trakia Journal of Sciences, 4(1):1-8.

4. World Health Organization. (2016). Global Reports on Diabetes, accessed https://apps.who.int, 20t May, 2020.

5. American Diabetes Association. (2001). Diabetes 2001: Vital Statistics.

6. Adewunmi, C. O., \& Ojewole, J. A. O. (2004). Safety of traditional medicines, complementary and alternative medicines in Africa. African Journal of Tradition, 1:1-3.

7. Okigbo, R. N., \& Mmeka, E. C. (2006). An appraisal of phytomedicine in Africa. KMITL Science Technology Journal, 6: 83-94.

8. Abubakar, U. S., Yusuf, K. M., Abdullahi, M. S., Abdu, G. T., Abdulrazak, A., Muhammad, S., Binta, I. K., Osodi, F. A., \& Aliyu, I. (2018). Cultivation, phytochemical and in vitro antiplasmodium activity of Artemisia annua L. (Asteraceae). Journal of Medicinal Plants Studies, 6(4): 151-155.

9. Yetendje, L. C., Njateng, S. S., Dogmo, A. A., Mouokeu, R. S., Feudjio, C., Tamekou, S. L., \& Iqbal, J. (2019). In vivo antidiabetic activity and mechanism of action of three Cameroonian medicinal plant extracts. International Journal of Research - Granthaalayah, 7(8): 415-430.

10. Auroba, N., Al-Abassi, N. A., Orooba, I., \& Nibras, N. A. (2010). Study of Antidiabetic Effect of Momordica charantia (bitter gourd) seeds on alloxan-induced diabetic rats. Iraq Journal of Vet Sciences, 34(1): 165-171.

11. Adeoye, A. T., Oyagbemi, A. A., Adedapo, A. D., Omobowale, T. O., Ayodele, A. E., \& Adedapo, A. A. (2017). Antidiabetic and antioxidant activities of the methanol leaf extract of Vernonia amygdalina in alloxan-induced diabetes in Wistar rats. Journal of Medicinal Plants for Economic Development, 1(1): 1-12.

12. Flora of Zimbabwe, accessed www.zimbabweflora.co.zw, 20 ${ }^{\text {th }}$ May, 2020.

13. Drewes, S. E., Horn, M. M., Munro, O. Q., Dhlamini, J. T. B., Meyer, J. J. M., \& Rakuambo, N. C. (2002). Pyrano-isoflavones with erectile dysfunction activity. Phytochemistry, 59: 739-747.

14. Ma, W. G., Fuzzati, N., Lu, S. L., Gu, D. S., \& Hostettmann, K. (1996). Further chromones from Eriosema tuberosum. Phytochemistry, 43: 13391343.

15. Ma, W. G., Fukushi, Y., Hostettmann, K., \& Tahara, S. (1998). Isoflavonoid glycosides from Eriosema tuberosum. Phytochemistry, 49: 251254.

16. Ojewole, J. A. O., Drewes, S. E., \& Khan, F. (2006). Vasodilatory and hypoglycaemic effects of two pyrano-isoflavone extractives from Eriosema kraussianum N.E. Br. [Fabaceae] rootstock in experimental rat models. Phytochemistry, 67(6):610-7.

17. Chukwuemeka, O. F. (2011). Effect of aqueous and ethanol leaf extracts of Eriosema psoraleoides on some oxidative stress parameters in alloxaninduced diabetic rats. (Unpublished thesis).

18. Ma, W. G., Fukushi, Y., Ducrey, B., Hostettmann, K., \& Tahara, S. (1999). Phenolic glycosides from Eriosema tuberosum. Phytochemistry, 51: 1087 1093.

19. Sofowora, A. (1993). Medicinal plants and traditional medicine in Africa. 2nd Edition. Spectrum Books Ltd, Sunshine House Ibadan Nigeria. 191-289.

20. Harbourne J. B. (1998). Phytochemical methods 3rd edition. Chapman and Hall; London. 84-131.

21. Lorke, D. (1983). A new approach to practical Acute Toxicity Test. Arch. Toxicol. 275-287.

22. Abo, K. A., \& Jimoh, T. B. (2004). Antihyperglycaemic potential of stem bark of Bauhinia monandra Kurz in rats. Nigerian Journal of Natural Products and Medicine, 8, 48-51.

23. Saravanamuttu, S., \& Sudarsanam, D. (2012). Antidiabetic plants and their active ingredients: A review. International journal of Pharmaceutical sciences and research, 3(10), 3639-3650. 
Nkemdirim A. Elechi \& Kio A. Abo; Saudi J Med Pharm Sci, June, 2020; 6(6): 474-479

24. American Heart Association. (2020). Cholesterol Abnormalities and Diabetes. Accessed www.heart.org , 26/2/2020.

25. Pradeep, K. D. (2010). Renal function in diabetic nephropathy. World Journal of Diabetes, 1(2): 4856.
26. Madianov, I. V., Balabolkin, M. I., Markov, D. S., \& Markova, T. N. (2000). Main causes of hyperuricemia in diabetes mellitus. Ter Arkh, 72(2): 55-8.

27. Elizabeth, A. A. (2005). Elevated liver function tests in Type 2 Diabetes. Clinical Diabetes, 23(3): 115-119. 